\title{
KONSEP MAQASHID AL-SYARI AH: PERBANDINGAN ANTARA PEMIKIRAN AL-GHAZALI DAN AL-SYATHIBI
}

\author{
Suansar Khatib \\ Fakultas Syariah IAIN Bengkulu \\ Jl. Raden Fatah Pagar Dewa Bengkulu \\ Email: suaka17@gmail.com
}

\begin{abstract}
This article explains the comparison of maqashid al-shari'ah thinking between al-Ghazali and al-Syathibi. The purpose and core of all Islamic teachings (Qur'an and hadith) is benefit. The need to prioritize the benefit of religious texts and ijma in the Muamalah region and adat if there is a contradiction between the two. Benefits prepared by humans must be included in the benefit of the text if there is a contradiction between the two. Both of them also agreed that the benefit was intended, the essence returned to the protection of humans themselves, but according to al-Thufi maslahah is the most authoritative independent proposition to determine legal policy. Benefit is not an authoritative proposition to determine legal policy. Benefit is not a legal proposition, but as the core and purpose of a law. According to him all the Islamic Shari'ah teachings have a causal relationship (muamalah) with benefit in the customary territory and muamalah. Intellect (intellect) of normal human beings can also know and find benefit in the area of muamalah and adat (tradition) not in the area of worship.
\end{abstract}

Keywords: maqashid al-syari ah, al-Thufi, al-Ghazali, al-Syathibi

\begin{abstract}
Abstrak: Artikel ini menjelaskan perbandingan pemikiran maqashid al-syari ah antara al-Ghazali dan al-Syathibi. Tujuan dan inti seluruh ajaran Islam (Alquran dan hadis) adalah kemaslahatan. Keharusan megedepankan kemaslahatan atas teks-teks agama dan ijma' dalam wilayah muamalah dan adat bila terjadi kontradiksi antara keduanya. Kemaslahatan yang disiapkan manusia harus diikutkan pada kemaslahatan yang dicanangkan teks bila terjadi kontradisksi antara keduannya. Keduanya juga sepakat bahwa kemaslahatan dimaksud, hakikatnya kembali pada perlindungan terhadap manusia itu sendiri, namun menurut al-Thufi maslahah adalah dalil mandiri yang paling otoritatif untuk menentukan kebijakan hukum. Kemaslahatan bukan dalil otoritatif untuk menentukan kebijakan hukum. Kemaslahatan bukan dalil hukum, melainkan sebagai inti dan tujuan sebuah hukum. Menurutnya seluruh ajaan-ajaran syariah Islam memiliki hubungan kausalitas (muamalah) dengan kemaslahatan dalam wilayah adat dan muamalah. Akal (intelektualitas) manusia normal mampu mengetahui dan menemukan kemaslahatan dalam wilayah muamalah dan adat (tradisi) tidak dalam wilayah ibadah.
\end{abstract}

Kata kunci: maqashid al-syari ah, al-Thuf, al-Ghazali, al-Syathibi

\section{Pendahuluan}

Bila ditelusuri perkembangan tentang maqashid al-syariah, maka diketahui bahwa perhatian terhadap maqashid al-syariah ini telah ada sejak masa rasulullah Saw. Meskipun ketika itu belum menyebut tema maqashid al-syariah secara jelas, tetapi setidaknya maqashid al-syariah telah memberikan warna dan kontribusi yang dapat dijadikan ukuran bagi legislasi hukum Islam sesuai dengan tujuan ditetapkannya hukum dalam Islam, yaitu mewujudkan kemaslahatan dan menolak kemudaratan (dar'u al- mafasid wa jalbu al-manafi'). Sebagai contoh, dapat ditelaah tentang anjuran Nabi saw. kepada para pemuda yang sudah memiliki kemampuan untuk segera menikah. ${ }^{1}$

\footnotetext{
${ }^{1}$ Hadits anjuran untuk pernikahan:

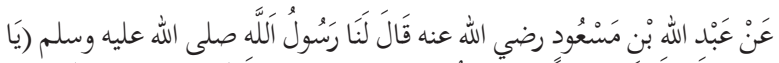

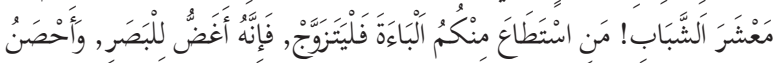

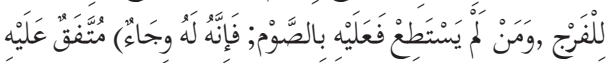

"Dari Abdullah bin Mas'ud. Ia berḱata: Telahbersabda Rasulúllah saw. Kepada kami: "Wahai generasi muda Barang siapa diantara
} 
Pada hadis tersebut terlihat adanya anjuran melakukan pernikahan agar tujuan syariat dapat dicapai, yaitu memberikan kemaslahatan bagi manusia itu sendiri, karena dapat menjaga pandangan mata dan memelihara kehormatannya dari hal-hal yang dapat merusak nilai-nilai kemanusian, seperti prostitusi dan sebagainya. Sedangkan bagi yang belum ada sanggupan untuk menikah dianjurkan pula untuk berpuasa, karena dengan berpuasa dapat mengendalikan hawa nafsu seksualnya. ${ }^{2}$

Kemudian dalam perkembangan selanjutnya, penelaahan terhadap maqashid al-syari ah mulai mendapat perhatian yang intensif setelah Rasulullah wafat, terutama ketika para sahabat dihadapkan dengan berbagai persoaalan baru dan perubahan social yang belum pernah terjadi pada masa Rasulullah saw masih hidup. Dengan adanya perubahan social sebagai akibat tuntunan zaman dan dinamika masyarakat, sehingga menuntut kratifitas para sahabat secara serius untuk melakukan penelaahan terhadap maqashid Al-syari ah sebagai upaya melakukan terobosan-terobosan hukum untuk mengantisipasi perubahan sosial yang terjadi. Di antara para sahabat Nabi saw yang paling sering melakukan kreasi dalam bidang hukum sebagai implikasi dari perubahan sosial itu adalah umar Ibn al-Khatab. ${ }^{3}$ Salah satu contoh yang sering dikemukakan oleh para ulama ushul adalah tentang pengucapan talak tiga sekaligus. Pada masa Nabi saw dan masa Abu Bakar dan di awal pemerintahan Umar Ibn Al-Khatab penjatuhan talak tiga sekaligus dihitung satu. Akan tetapi waktu itu, Umar Ibn Al-Khatab memutuskan

kamu telah mampu berkeluarga hendaklah kawin, karena ia dapa tmenundukkan pandangan dan memelihara kemaluan; dan barang siapa tidak mampu, maka hendaklah ia berpuasa, sebab ia dapat mengendalikanmu'. Muttafaq 'alaihi.

${ }^{2}$ Ada beberapa hadits lain yang dianggap memiliki muatan, maqashid al-syari'ah, seperti hadits yang berisikan tentang perintah Nabi untuk menyimpan daging qurban, hadis larangan ziarah kubur pada awal-awal Islam, dan lain-lain.

${ }^{3}$ Sebenarnya masih banyak kreatifitas sahabat yang lain melakukan trobosan untuk menghadapi perubahan social yang terjadi sepeninggalan Nabi Muhammad saw., namun dalam kesempatan ini penulis hanya mengemukakan salah satu contoh dari umar Ibn Al-khatab. bahwa penjatuhan talak tiga sekaligus itu dianggap thalaq tiga. ${ }^{4}$ Keputusan Umar Ibn AlKhatab ini adalah untuk menutup terjadinya peluang tindakan semena-mena para suami yang waktu itu seringkali berbuat sewenang-wenang menjatuhkan thalaq kepada istri-istrinya. Selain itu juga, untuk menjaga eksistensi fungsi talak itu sendiri dan mengembalikan kepada fungsi yang sebenarnya, yakni talak sebagai hak suami tidak diselewengkan sebagai alat menganiaya istri. Dengan demikian, pertimbangan hukum yang dilakukan Umar Ibn Al-Khatab di atas, sesuai dengan maqashid al-syari'ah. Karena itu, ijtihad Umar Ibn Al-Khatab ini sesuai dengan adagium fikih yang menyatakan bahwa "perubahan suatu fatwa tergantung kepada perubahan zaman, keadaan, dan kebiasaan masyarakat itu. ${ }^{5}$

Sebelum memaparkan pemikiran at-Thufi, al-Ghazali dan al-Syathibi tentang maqasid alSyari'ah, perlu di telusuri sekilas tentang perkembangan maqashid al-syari'ah itu sendiri. Sebab secara geneologis rancang bangun pemikiran maqashid al-syariah bukanlah capaian baru, meskipun baru dikenal sebagai suatu disiplin ilmu yang berdiri sendiri pada masa Imam al-Syathibi. Akan tetapi, bukan berarti bahwa dalam tradisi para ulama klasik tidak membahas tentang maqashid alsyariah. Hanya saja pengungkapannya terangkum dalam pembahasan yang berbeda, namun memiliki subtansi yang sama. Ada yang menyebut dengan istilah al-illat,al-hikmah, al-maslahah, murad alsyar', asrar al-syari 'ah dan istilah-istilah lainnya yang merupakan cikal bakal maqasid al-syari ah dan pembahasan-pembahasan yang berkaitan dengannya.

Dalam lintasan sejarah, sebenarnya almaqashid al-Syari'ah sendiri menurut Ahmad Rasyuni $^{6}$ pertama kali digunakan oleh $\mathrm{Abu}$ 'Abdillah Muhammad bin 'Ali al-Tirmidzi yang

${ }^{4}$ Muhammad Said Ramadhan al-Buthi (selanjutnya disebut Al-buthi), al-Dawabit al-mushlahat $f$ al syariah al-islamiayah, (Beirut":Muasasah Al-Risalah, 1977), h..140-141

${ }^{5}$ Ibn Qayyim al-jauziah (selanjutnya Ibn Qayyim), I'lam Al Muwaqin'in An Rab Al-Alamin, (Beirut: Dar al Fikr,t,th.), Juz III, h..14

${ }^{6}$ Guru Besar Usul Fikih Universitas Muhammad V, Rabat, Maroko 
populer dengan sebutan Alhakim al-Tirmidzi (w. akhir abad ke 3H). Dialah yang pertama kali menyalurkan Maqashid al-Syariah melalui buku-bukunya: al-shalat wa maqashiduhu, alwaj wa asraruh, al-illah, 'ilal al-syariah, 'I'al al-ubudiyyah dan juga bukunya al-Furuq yang kemudian diadopsi oleh Imam Syihab alDin Al-Qarafi (w.685 H) menjadi judul buku karangannaya. ${ }^{7}$

Setelah al-Hakim menggulirkan ide genialnya tentang hikmah-hikmah shalat, kemudian muncullah pula Abu Mansur al-Maturudi (w.333. H) dengan karyanya Ma’khad al-Syara disusul Abu Bakar al-Qaffal al-Syasyi (w.365.H). dengan bukunya Ushul al-Fiqh dan Mahasin alSyari'ah. Setelah al-Qaffal muncul al-QAFFAL muncul Abu Bakar al-Abhari (w.375 H.) dan al-Baqallany (w.403 H) masing masing dengan karyanya, di antaranya, mas'alah al-jawab wa aldalail wa al illah dan al-Taqrib wa al-Irsyad $f i$ tartib thuruqal-ijtihad. Kemudian sepeninggalan al-Baqillany muncullah al-juany (w. $478 \mathrm{H}$ ), al-Ghazali (w.505 H), al-Razy (w.606 H), alAmidy (w.631 H), Ibnu Hajib (w.646 H), alBaidhawi (w.685 H), al-Isnawi (w.772 H), ibnu Subuki (w.716 H), ibnu abd al-Salam (w. $728 \mathrm{H}$ ), dan ibnu al-Qayyim (w.751 H) $)^{8}$. Deretan pakar-pakar tersebut secara kongkrit menunjukan bahwa diskursus maqashid tak lain merupakan akumulasi pemikiran para teoritisi hokum sepanjang sejarahnya.

Kemudian gagasan genial yang dicetuskan oleh Abu al-Ma’ali Abdul malik bin Abdullah alJuwayni (w. $478 \mathrm{H}$ ) ini disimpilkan dan dielaborasi murisnya Muhammad bin Muhammad al-Ghazali (w.505 H) untuk memetakan maqasid al-syariah menjadi kulliyah-universal dan juz'iyyah-parsial yang ditetapkan dalam karyanya al-Mankhul, syifa' al-Ghalil, Ihya' Ulum al-Din, dan al-Mustasfa.

Pada priode berikutnya muncul Najmuddin atThufi (w. $716 \mathrm{H}$ ), yang membahasakan maqasid

\footnotetext{
${ }^{7}$ Ahmad Raisuni, Nadhariyyat al-Maqashid 'Inda al-Imam al-syathibi, (Beirut : al-Muassasah al-Jami'iyyah Liddirasat wa al-Nasyr wa al-Tauzi', 1992), h.. 32.

8 Ahmad Raisuni, Nadhariyyat al-Maqashid..., h. 40-71
}

syariah dengan al-mashlahah. Karena menurutnya subtansi dan urat nadi kajian maqasid al-syariah ini adalah mashlahah (wefere, benefit dan utility). Artinya tujuan pokok dan pelembangan hokum dalam islam adalah untuk merealisir kemaslahatan dan menghindarkan manusia dari berbagai macam kesulitan dan kemudharatan. Untuk itu Allah Swt dalam mentransformasikan hukum Islam (dalam konteks syariah) kepada mahluknya mengandung maksud-maksud, motif-motif dan tujuan-tujuan sebagai sasaran akhir yang ingin dicapai, yang semuanya itu adalah untuk kepetingan dan kemaslahatan mahluknya baik di dunia maupun akhirat. Kemudian konsep tentang maqasid ini lebih disempurnakan lagi oleh Abu Ishaq al-Syatibi yang terkenal dengan karya al-Muwafaqat.

\section{Sekilas tentang Al-Thufi, Al-Ghazali dan Al-Syathibi}

\section{Najmuddin At-Thufi}

Najmuddin Abu Rabi' Sulaiman bin Abdul Qawi nin Abdul Karim bin Said at-Thufi alBaghdadi adalah seorang ilmuan yang lahir di Thufa, sebuah desa yang berada dua dua kilometer dari Baghdad. Menurut ibnu hajar, al-Thufi lahir tahun 657, sedangkan menurut Mustafa Zaid, al-Thufi lahir pada tahun 670, namun mereka sepakat bahwa al-Thufi wafat tahun $716 .{ }^{9}$

Al-Thufi muda mempersiapkan dunia intelektualnya mulai dari daerah kelahirannya sendiri, Thufa, dengan belajar kepeda beberapa orang ulama mazhab Hambali. Ia menguasai serta menghafal (hafidza) beberapa kitab, antara lain, kitab fiqih mazhab hambali yang bernama Mukhtasar al-khiraqi karya Umar al-Khiraki (w.334 H) dan al-Lumma' tentang sasra Arab karya Ibnu al-janni (w.392 H) salah seorang tokoh ilmu nahu dan bahasa arab.

Tidak cukup di kampungnya, al-thufi menurut ilmu ke Sarsar untuk berguru kepada Taqqiyuddin al-Zarirani (mufti Iraq, w. 729 H) al-Nashr al-Faruqi dalam bidang Usul Fikih,

\footnotetext{
${ }^{9}$ Mustafa Zaid, al-Maslaha fi Tasri' al-Islami wa Najmuddin at-Thufi, (Dar al-Fikr al-Araby, 1964), h.235
} 
Abu Bakar al-Qalinisi tentang Damsyiq dan berguru kepada Taqiyuddin al-Maqdisi (Qadhi al-Qudhat Syam, w. 715 H), d sini sempat bertemu dengan Ibnu Taymiah (w. $728 \mathrm{H}$ ) dan al-Mizzi al-Syafii (w.742 H)

Setelah setahun di Damsyiq, at-hufi melanjutkan ke mesir pada tahun 705 dan berguru serta berdidkusi dengan beberapa ulama besar di sana, diantaranya al-Dimyati (w. $705 \mathrm{H}$ ), alHirisi (w. $711 \mathrm{H}$ ) dan Abu Hayyan al-Nahwi $(745 \mathrm{H})$. Di Mesir, ia sempat di penjara karena dituduh menganut faham Syiah Rafida. Keluar dari penjara yang jusru lebih membuatnya banyak waktu untuk membaca dan menulis karya-karyanya, at-Thufi berangkat ke Hijaz dan berhaji pada tahun 715 dan menyempatkan belajar serta menerima hadits dengan ulamaulama Hijaz. Sepulang dari Hijaz at-Thufi ke Syam dan kemudian ke Palestina dan wafat di Bitul Maqdis dalam usia 59 tahun.

Para sejarawan yang menulis riwayat hidupnya menjelaskan bahwa sejak berada di bagdad, at-thufi telah diakui tidak saja sebagai seorang ulama fiqih dan ushul fiqih mazhab hambali yang sangat dalam ilmunya, tetapi juga sangat menguasai bidang fiqih dan ushul fiqih mazhabmazhab lainnya. Di samping itu ia juga diakui sebagai ulama dalam bidang ilmu sejarah, ilmu kalam, tasawuf, mantiq, tafsir, hadits, sasra, syair dan bahasa arab.

Para ulama menyimpulkan bahwa at-Thufi bermazhab hambali, namun dalam hal ini terdapat dua catatan, yakni: pertama, ia menjadi ulama mazhab Hambali hanya sejak ia memulai karir ilmiahnya sampai selama ia berada di Baghdad. Ia menganut mazhab Hambali tidak menjadika dirinya terkekang dalam belenggu fanatic mazhab, sebagaimana yang umum terjadi di kalangan ulama pada masanya. At-Thufi memiliki keyakinan bahwa kebebasan berfikir selama dalam batas-batas kemampuan yang dimiliki manusia untuk menemukan kebenaran adalah tindakan yang terpuji menurut ajaran Islam.

Kedua, setelah ia meninggalkan Bagdad, se- tidaknya setelah ia menulis kitab Syara al-Arbain al-Nawawiyyah dapat dismpulkan bahwa ia telah membebaskan diri dari Mazhab, khususnya mazhab Hambali. Dengan kata lain ia telah sampai ke tingkat mujtahid mustaqil (mujtahid mandiari).

Adapun tentang akidah at-Thufi dapat disimpulkan bahwa ia berhaluan ahlu Sunnah wal jamaah, walaupun sempat ada tuduhan bahwa ia menganut Syiah Rafidhah tapi semua itu tidak didukaung oleh argument yang memadai.

At-Thufi termasuk penulis yang cukup produktif, diantara karyanya adalah adalah syarah arbain al-nawawiyyah (sudah ditahqiq oleh dr. Mustafa Zaid), Isyarat al-Ilahiyyah ila al-Mabahits al-ushuliyyah (ditahqiq oleh kamal Muhammad isa), Halal al-aqd fi bayan Ahkam al-Mu'tamad, al-Iksir fi Ulum al-tafsir, Mukhtasar at-Tirmizi, mi'raj al-Wushul ila ilmi al-Ushul, Ta’aliq ala al-Anajil, dan lain-lain yang jumlahnya mencapai 48 (empat puluh delapan) buah karya.

\section{Al-Ghazali}

Nama lengkapnya Abu Hamid Muhammad binMuhammad bin Muhammad bin Ahmad al-Ghazali at-Thusi al-Syafi'I, yang terkenal dengan gelaran hujjail islam al-Imam al-jalil Zain ad-Din (argumentator Islam) mengingat jasanya yang benar di dalam menjaga islam dari pengaruh ajaran bid'ah dan aliran rasionalisme yunani. Lahir pada tahun $450 \mathrm{H}$ di desa Ghazalah, di pinggir kota Thus (yang pada hari ini terletak di bagian Timur laut Negara iran). ${ }^{10}$

Al-Ghazali memlaui pendidikannya di wilayah kelahiran, ia belajar Alquran dan dasardasar ilmu keagamaan yang lain kepada ayahnya, kemudian al-Ghazali dan adiknya belajar fiqih dari Ahmad ibnu Muhammad al-Razakny atThusu di Thus dan tasauf dari Yusuf an-Nassaj,

${ }^{10}$ Lihat Sulaiman Dunya, al-Haqiqah fi Nazhr Al-Ghazali, (Kairo: Dar al-Maarif, 1971), h. 19. Bandingkan Abu Abbas Syamsudin Syamsuddin Ahmad bin Muhammad ibn Abi Bakr ibn Khalikan, al A'yan wa Anba' Abna' al-Zaman, (Beirut: Dar al-Shaadir, 1971), Juz IV, Cet I, h. 216-219. 
kemudian hingga $470 \mathrm{H}$. Al-Ghazali, belajar ilmu-ilmu dasar yang lain, termasuk bahasa Persia dan arab pada nasr al-Ismail di Jurjin. ${ }^{11}$ Pada usia 20 tahun telah menguasai bebarapa ilmuilmu dasar dan dua bahasa pokok yang lazim dipergunakan oleh masyarakat ilmiah ketika itu, sehingga dua bahasa ini mengantarkan dalam memahami buku-buku ilmiah secara otodidak. ${ }^{12}$

Pada tahun $473 \mathrm{H}$. Al-Ghazali pergi ke naisabur untuk melanjutkan pendidikan pada madrasah anNizamiyyah, ketika itu Abu al-Ma'ali Abdul malik bin Abdullah al-Juwayni yang dikenal dengan Imam al-Haramain $(478 \mathrm{H})$ bertindak sebagai kepala dan tenaga pengajar di sana. ${ }^{13}$ Di sinilah ia memperoleh dan memahami fiqih dan unsul fiqih, mantiq (logika) dan ilmu kalam dari aliran Asy'ariyah maupun selainya yang berkembang pada waktu itu. Imam Haramain menjuliki AlGhazali dengan sebutan Bhar Mu'riq (lautan yang menghanyutkan) karena dalam menguasai ilmu yang di dapatnya, termasuknilmu retorika sehingga dia mampu memberikan sanggahansanggahan kepada para penentangnya. ${ }^{14}$

Al-Ghazali dikenal juga sebagai filosof, sufifaqih dan usuli. Di bidang ilmu kalam, al-Ghazali merupakan tokoh mutakalimin Asyaeri'ah. Sementara di bidang hokum islam (fiqih dan Ushul fiqih), beliau merupakan tokoh Syafi' iyah. ${ }^{15}$

Berselang bebarapa tahun setelah aljaini wafat (w. $478 \mathrm{H}$ ). terpatnya pada tahun $484 \mathrm{H} / 1091$ $\mathrm{M}$, Imam Al-Ghazali diangkat menjadi guru besar dimadrasah Nidzhamiyah di Baghdad. Ini adalah suatu pencapaian yang sangat tinggi, karena dalam usia baru 34 tahun, al-Imam Abu Hamid al-Ghazali Telah diberikan gelar syeikh al-islami, yakni pangkat yang tertinggi bidang akademik dan keagamaan.

\footnotetext{
${ }^{11}$ Sulaiman Dunya, al-Haqiqah fi Nazhr..., h. 20.

12 Sholeh Ahmad Syamy, Al-Imam al-Ghazali Hujjatu alIslam wa Mujaddid al-Mi'at al-Khamisah. (A'lam al-Muslimin Seri 43), (Damsyiq: Dar al-Qalam, 1993/1413), Cet I, h. 20

${ }^{13}$ Sholeh Ahmad Syamy, Al-Imam al-Ghazali..., h. 21

${ }^{14}$ Ahmad Fuad al-Ahwani, Sirah al-al-Ghazali wa al-Aqwal al-Mutaqaddimin fih, (Damaskus: Dar al-Fikr,t.th), h. 7.

15 Ibn al-Subuki, Tabaqat al-Syafiiyah al-Kubra, (Kairo: Matba'ah 'Isa al-Babi al-Halabih, t.th), jilid VI, h. 197-209.
}

Imam al-Ghazali meninggal dunia menjelang matahari terbit di kota kelairannya (thus), tepatnya pada hari senin 14 jumadil Akhir 505H/ $1111 \mathrm{M}$ ), dan di makamkan di Zhahahir al-tabiran, Ibukota Thusi. ${ }^{16}$

Karya ilmiah yang ditinggalkan dalam berbagai cabang ilmu keagamaan, mulai dari fiqh, ushul fiqh, ushul al-din, mantik, jidal, khilaf filsafat hingga tasauf. ${ }^{17}$ Diantara keryanya yang terkenal adalah tahafut al-falasifah,Al-Muqidz min al-Dhalal, al-Musthashfa min 'Ilm al-Ushul dan ihya Ulum al-Din. ${ }^{18}$

\section{Abu Ishaq al-Syatibi}

Nama lengkap Imam Syathibi Adalah Abu ishak Ibrahim bin Musa bin Muhammad Allalhami al-Gharnathi. Ia dilahirkan di Granada

${ }^{16}$ Sholeh Ahmad Syamy, Al-Imam al-Ghazali..., h. .22-23

${ }^{17}$ Lebih lanjut lihat untuk mengetahui nama-nama kitap karya al-Ghazali dari berbagai bidang ilmu tersebut, lihat Ibn Syubhan Taqiqyudiddin Abi Bakr nin Ahmad bin Qadhi syuhbah al-Asady al-Dimasqy, Taqabaqat al-Fuqaha al-Syafiiyyah, juz, (Kairo: Maktabah al-Tsaqafah al-diniyah, t.th), h.. 279-280.

${ }^{18}$ Di antara kitab-kitab al-Ghazali: Al-Ma’rif al-Aqilyyah wa al-Hikmah al-Ilahiyyah;, karya al-Ghazali ini berupa naskah yang terdapat di dua perpustakaan yaitu Paris dan Oxford, Maqashid al-Falsafah, buku ini dikarang oleh al-Ghazali sebagai pendahuluan buku al-Tahafut, Tahafut al-Falasifah, al-Munqidz min al-Dhalal, karya tulis al-Ghazali ditulis pada tahun 501-502 H. 29 ketika ia menetap kedua kalinya di Naisabur, Al-Madnun bih 'ala Ghair, Fatiha al-Ulum, karya ini berupa naskah tulisan tangan (naskah Khaththiiyyan.) tersimpan di perpustakaan paris. Haqai al-Ulum, karya bentuk naskah yang yang juga tersimpan di perpustakaan paris, Maqashid al-Qulub al-Matrahbah ila allam Ghuyub, mi'yar al-ilm, minhaj al-Nadz, Ma-arij al-Quds fi Madarid márifah al-Nafs. Jam al-Haqiq fi Tajrad al-a’laiq, ihya Ulumu al-Din, karya besar al-Ghazali menghidupkan kembali ilmu-ilmu agama Islam seperti logika, ahlaq, tasauf, dan sebagainya. Buku ini mempunyai syarah yang banyak antara lain: ittahaf al-al-sadat al-Muttawin (13 julid), taj al-Qasdihin (ibn al-Jauih) Ruj al-Ihya' (Ibn Yunus), bidayah al-hudayah, kitab mizan al-Amal, karang al-Ghazali ditulis dibahdad, sebelum memasuki dunia thasauf, buku itu merupakan pelengkap untuk menjelaskan pengertian yang ada di dalam Ihya' kurang jelas, AlQisthas al-Mustaqim, kitab al-Sa'adah, Ayyuha al-walad, kitab al-Mankhul fi il,I Ushul, (kitab pilihan tentang Ushul figh), al-Musthafa min ilm al Ushul (tempat pembersihan dan ilmu Ushul Figh), merupakan kitab yang sangat terkenal dalam ushul fiqh. Yang sangat popular dari buku ini ialah pengantar manthiq dan pembahasan ilmu kalamnya, dalam kitab ini imam Ghazali membenarkan perbuatan ahli kalam yang mencampur adukan pembahasan usul fiqih dengan pembahasan ilmu qalam. Lebih lanjut lihat Ahmad al-Ahwi, Sirah al-Ghazali wa al-Aqwal alMutaqqaddimin fih, h..66 
pada tahun $730 \mathrm{H}$. dan meninggal pada sela tanggal 8 sya'ban tahun $790 \mathrm{H}$ atau $1388 \mathrm{M} .{ }^{19}$ Nama Syathibi adalah nisbat kepada tempat kelahiran ayahnya di Sativa (Syathiban-Arab), sebuah daerah di timur Andalusia. Pada tahun $1247 \mathrm{M}$, maka keluarga al-Syathibi mengungsi ke Granada setelah sativa, tempat asalnya, jatuh ke tangan Raja Spanyol Ueaqun setelah keduanya berperang selama kurang lebih 9 tahun sejak tahun $1239 \mathrm{M}$.

Ketika al-Syathibi hidup, Granada diperntah oleh Bani Ahmarr. ${ }^{20}$ Bani Ahmar sendiri adalah sebutan untuk keturunan dan keluarga Sa'ad bin Ubadah, setelah seorang sahabat Anshar. Sedangkan laqab Ahmar ditujukan kepada salah seorang rajanya yang bernama Abu Sa'id Muhammad as-Sadis $(761-763 \mathrm{H})$ karena memiliki warna kulit kemerah-merahan. Orang Spanyol menyebut Abu Sa'id dengan al-Barmekho yang dalam bahasa Spanyol berarti warna jeruk yang kemerah-merahan. ${ }^{21}$

Ketika bani Ahmar berkuasa, kehidupan masyarakat jauh dari kehidupan yang islami bahkan mereka dipenuhi dengan berbagai khurafat dan bid'ah. Kondisi ini semakin parah ketika Muhammad al-Khamis yang bergelar alGhany Billah memegang kekuasaan. ${ }^{22}$ Bukan hanya seringnya terjadinya pertempahan darah dan pemberontakan, akan tetapi pada masa itu juga setiap ada yang menyeru kepada cara beragama yang sebenarnya malah dituding telah keluar dari agama bahkan acap kali mendapat hukuman yang sangat berat.

\footnotetext{
${ }^{19}$ Sebetulnya tempat kelahitan imam syathibi tidak diketahui secara persis apakah di Granada atau sativa. Karena dalam buku teks buku al-ifadat sendiri hanya disebutkan bahwa imam syatibi itu nasya bi gharnathah, hanya tumbuh bukan dilahirkan. Demikian juga dengan tahun kelahirannya. Akan tetapi keterangan lainnya, maka para penulis berikutnya menjadikan Granada sebagi tempat kelahirannya. Demikian juga dengan tahun kelahirannya, ada yang menyatakan ia lehir sebelum tahun $720 \mathrm{H}$ ada juga yang setelahnya. Lihat al-Tanbakati, Nailul Ibtihaj, h.. 46, Abu al-Ajfan, al-Ifadat h.151 dan Hammady al-Ubaidi, al-Syathibi wa Maqashid al-Syariah, h. 11

${ }^{20}$ Daulah ini Berjaya selama dua abad enam puluh dua tahun yaitu sejak tahun 635-897H. dengan runtuhnya Bani Ahmar ini sekali gus mengakhiri kehadiran Islam di andalusia

${ }^{21}$ Hammady, al-Syathibi wa Maqashid..., h. 29

${ }^{22}$ Hammady, al-Syathibi wa Maqashid..., h..31
}

Hampir semua ulama yang hidup pada masa itu adalah orang-orang yang tidak memiliki latar Belakang ilmu agama yang cukup dan bahkan tidak jarang mereka yang tidak tahu manahu persoalan agama diangkat oleh raja sebagai dewan fatwa. Oleh karena itu, tidaklah heran apabila fatwa-fatwa yang dihasilkan sangat jauh dari kebenaran.

Imam Syathibi bangkit menentang dan melawan para ulama Granada saai itu. Ia mencoba meluruskan dan mengeimbalikan bid'ah ke sunnah serta membawa masyarakat dari kesesatan pada kebenaran. Perseteruan sengit antara imam Syathibi dan para ulama Granada saat itu tidak dapat dielakkan. Setiap kali Imam Syatibi berfatwa halal, maka sebaliknya, berfatwa haram tampa melihat terlebih dahulu kepada nash. Karena itulah, imam Syathibi kemudian dilacehkan, dicerca, dikucilkan dan dianggap telah keluar dari agama yang sebenarnya.

Hal lain yang disorot Imam Syatibi adalah praktek tasawwuf para ulama saat itu yang telah menyimpang. Maka mereka berkumpul malam hari, lalu berdzikir bersama dengan suara sangat keras kemudian diakhiri dengan nyanyian samopai akhir malam. Sebagian dari merekayang memukul dadanya dan kepalanya. Sendiri. Imam Stathibi bangkit mengharamkan peraktek tersebut karena menyimpang dinilai telah menyimpang dari ajaran yang sesungunya. Menurut imam Syahibi, setiap cara mendekatkan diri yang ditrmpuh bukan seperti yang dipraktekkan Rasulullah SAW dan para sahabatnya adalah bathil dan terlarang. ${ }^{23}$

Fatwa al-Syathibi tentang praktek tasawwuf yang menimpang ini juga dikuatkan oleh salah seorang ulama ahli tasawwuf saat itu Abu hasan an-Nawawi. Ia mengatakan bahwa barang siapa yang melihat orang yang mendekatkan diri kepada Allah SWT dengan jalan yang keluar dari ilmu syar'ah, maka jangan mendekatinya.

Imam Syathibi juga menyoroti ta'ashub berlebihan yang diperaktekkan para ulama

23 Abu Ishaq al-Syathibi, al-I'tisham, (Beirut: Dar alMa’rifah, 1982), juz I, h. 264. 
Granada dan masyarakat andalusia saat itu terhadap madzhab Maliki. Mereka memandang setiap orang yang bukan madzhab maliki adalah sesat. Sebagaimana diketahui bersama bahwa masyarakat andalusia memang erat madzhab maliki ini sejak raja mereka Hisyam al-Awwal bin Abdurrahman ad-Dakhil yang memerintah dari tahun $173-180 \mathrm{H}$ menjadikan madzhab ini sebagai madzhab resmi negara.

Menurut salahsatu riwayat, kecendrungan Hisyam al-Awwal untuk mengambil madzhab Maliki ini adalah ketika dia bertanya kepada dua orang ulama yang satu bermadzhab Hanafi serta yang lain bermadzhab Maliki. Hisyam Al Awwal saat itu bertanya:"darimana asalanya abu hanifah itu" ulama Hanaifi menjawab:" dari Kufah". Lalu ia bertanya kembali kepada ulama Maliki: "darimana asal Imam Malik?” ulama maliki menjawab "dari Madinah". Hisyam lalu berkata:" Imam yang berasal dari tempat hijrah Rasulullah yang cukup jauh dari kami”. Maka saat iti, seolah sudah merupakan amar resmi, masyarakat Andalus memegang kokah madzhab Maliki. Saking berlebihnya ta'asub mereka, mereka tidak lagi mengenal bahkan cenderung tidak bersahabat dengan madzhab-madzhab lainya terutama madzhab hanafi sehingga muhammad Fadhil bin Asyur melukiskan mereka: "mereka idak lagi mengenal selain alqur'an dan al-Muwatha' imam malik".

Para ulama yang tidak bermadzhab Maliki saat ini tidak pernah lepas dari cercaan bahkan penyiksaan seperti yang di alami oleh alAlammah baqa bin Mukhlid, seorang ulama besar bermadzhab hanafi. Imam Syathibi melukiskan ulama ini sebagai ulama besar yang tidak ada tandingannya saat itu, ia pernah belajar dari Abu Hanifah, Ahmad bin hambal dan ulama-ulama lainnya yang berada di luar Andalus. Namun, sayang meninggal karena hukuman dari amir saat itu.

Sekalipun Imam Syathibi seorang ulama Maliki bahkan Muhammad makhluf menjadikannya sebagau ulama maliki tingkatan ke 16 cabang andalus, namun ia tetap menghargai ulama-ulama madzhab lainnya termaksuk madzhab hanafi yang sesat saat ituselalu menjadi sasaran tembak nomor satu. Bahkan, dalam berbagai kesempatan ia sering menyunjung Abu Hanifah dan ulama lainnya. Kitab alMuawafaqat sendiri sengaja disusun oleh imam Syatibhidalam rangka menjembatani ketegangan yang terjadi saat itu antara madzhab Maliki dan Hanafi.

Sedangkan sebagai respon terhadap bid'ah dan khufarat yang berkembangan saat itu, imam Syathibi menyusun sebuah karya lainnya berjudul al-I'tisham.

Karya-karya Imam Syathibi semuanya mengacu kepada dua bidang ilmu yang menurut istilah hammadi al-Ubaidy, ulum al-wasilah dan ulum al-maqasid. Ulum al-wasilah adalah ilmuilmu bahasa arab yang merupakan wasilah untuk memahami ilmu Maqasid. Berikut ini karyakarya Imam Syathibi: kitab al-Muwafaqat, kitab al-I'tisham, kitab al-majlis, syarah al-khulashah, Unwan al-Ittifaq, Ushul an-nahw, Al-Ifadaat wa al-Insyadaat, fatwa al-Syathibi. Di antara sekalian banyak karya Imam Syathibi ini, yang di cetak hanya tiga buah yaitu kitab al-Muwafaqat, kitab al-I'tisham dan al-Ifaadat wa al-Insyadaat.

\section{Maqashid Al-Syariah dalam pandangan al-Thufi, al-Ghazali dan al-Syatibi}

Meskipun di kalangan ulama ushul terdapat perbedaan istilah antara satu dengan lainnya. Muhammad Abu Zahra misalnya, menyebutnya dengan maqasid al-ahkam. Semenjak Zaky al-Din Sya'ban dan Abdul Wahab Khalaf, mengistilahkan dengan maqasid al-tasri. Najmuddin al-Thufi lebih banyak membahasakannya dengan al-maslahah, sedangkan maqashid al-syari'ah merupakan istilah yang digunakan oleh Imam Ishaq al-Syathibi dan Abdul Karim Zaidan, namun pada prinsipnya perbedaan istilah itu sebenarnya mengandung pengertian sama. Untuk menghindari kekeliruan dan kesimpangsiuran pemakaian istilah, maka dalam tulisan ini akan digunakan istilah maqashid al-syariah semata.

Dilihat dari segi kebahasaan, kata "maqasahid 
al-syariah" terdiri dari dua penggalan kata, yaitu "Maqashid" dan "al-syari'ah" yamh masing-masing punya makna tersendiri. Kata "maqashid" merupakan bentuk plural (jama') dan kata "maqashid". Sedangkan akar katanya berasal dari kata verbal "qashada", yang berarti menuju; bertujuan; berkeinginan dan berkesengajaan. Sedangkan pengertian "syari'ah' secara harfiah adalah sumber mata air atau sumber kehidupan. Kata "syari'ah" (tunggal) jamak "syara'i" berarti segala yang diisyaratkan Allah kepada hambanya, di antaranya berupa aturan-aturan hukum. Perkataan "syari'ah" berarti peraturan, sesuai dengan makna yang dijumpai dalam Alquran surat al-Jatsiyah ayat 18: (kemudian kami jadikan kamu berada di atas syariat(peraturan atau undang-undang) dari urusan (agama) itu).

Dengan demikian, secara etimologis maqasahid al-syariah berarti tujuan Allah (Pembuatan hukum) menetapkan hukum terhadap hambanya, yang inti dari penerapan Syari'at itu berorintasi untuk mewujudkan kemaslahatan umat manusia.

Kemudian dalam terminologo syari'at terdapat dikalangan para ulama yang otoritatif dalam bidang ushul tentang pengertian maqashid al-syariah. Dalam kaitan ini, Abu Ishaq alSyatibi (w. 790H/1388 M) dalam bukunya "alMuwafaqat" menandaskan" bahwa yang dimaksud dengan maqashid al-syariah ialah ketentuanketentuan hukum yang disyariatkan Allah untuk kemaslahatan manusia. Begitu pula, menurut 'Allal al-Fasiy dalam karyanya menyebutkan bahwa yang dimaksud dengan maqashid al-syariah adalah tujuan yang dikehendaki syara' dan rahasia-rahasia yang ditetapkan (Allah) pada setiap hukum. Adapun inti dari Maqashid Al-Syariah itu sendiri adalah tujuan yang dikehendaki syara' adalah untuk mewujudkan kebaikan sekaligus menghindari keburukan, atau menarik manfaat dan menolak mudharat. Atau dengan kata lain seperti yang ditegaskan al-Syatibi bahwa tujuan utama Allah menetapkan hukumnya adalah untuk terwujudnya kemaslahatan hidup manusia di dunia dan di akhirat. Oleh sebab itu, taklif (pembenaan hukum) harus mengacu kepada wujudnya tujuan hukum itu. Sebab menurut al-Qardawi di mana ada maslahat, dilaksanakan hukum Allah.

Dengan demikian, lihat secara jelas bahwa betapa eratnya hubungan antara maqashid al-syariah (tujuan hukum Islam) dengan kemaslahatan (maslahat). Pemeknaan terhadap maslahat para ulama mengungkapkannya dengan definisi yang berbeda-beda. Menurut al-Khawaizmi (w.790H/1388M) menyatakan maslahat merupakan pemeliharaan terhadap tujuan hukum Islam dengan menolak bencana/ kerusakan/hal-hal yang merugikan dari mahluk (manusia).

Sementara menurut al-Thufi, maslahat secara urf merupakan sebab yang membawa kepada maslahat (manfaat), sedangkan dalam hukum Islam, maslahat merupakan sebab yang membawa akibat bagitercapainya tujuan Syar'I (Allah) baik dalam bentuk ibadat maupun ma'amalah.

Sedangkan menurut al-Ghazali, maslahat makna asalnya merupakan maslaha dalam hukum Islam adalah setiap hal yang di maksudkan untuk memelihara tujuan syariat yang pada intinya terangkum dalam al-mabaadi' al-khamsyah yaitu perlindungan terhadap agama (hifzd al-din), jiwa (hifzd al-nafs) akal (hifzd-'aql), keturunan (hifdz al-nasl), dan harta (hifzd al-maal). Setiap hukum yang mengandung tujuan memelihara kelima hal tersebut disebut maslahat, dan setiap hal yang membuat hilangnya lima unsur ini disebut mafsadah.

Dari beberapa pengertian yang dikemukakan diatas, dapat dipahami bahwa yang dimaksud Maqashid Al-Syariah adalah tujuan Allah menetapkan hukum-hukum untuk mencapai kemaslahatan hidup manusia, sekaligus juga menghindari berbagai kerusakan, baik di dunia maupun akhirat.

Lebih jauh dimaksud at-Thufi tentang almaslaha disini adalah al-muslaha yang sejalan dengan tujuan syara'. Ia berbeda dengan maslaha mursalah yang dinisbahkan kepada mazhab Maliki. Maslaha dalam pengertian at-Thufi lebih luas dari pada itu. Namun dalam hal ini, 
at-Thufi tidak membagi menjadi tiga tingkatan menjadi dharuriat, hajiat dan tabsiniat. Dan hal lain yang membedakan Thufi dengan ulama lainnya adalah bahwa al-maslaha itu terbatas hanya pada hal muamalah, bukan ibadah.

Menurut al-Ghazali, menjaga kelima kelima pokok yang telah disebut di atas (perlindungan terhadap agama, jiwa, akal keturunan dan harta) merupakan peringkat al-Dharurat (sangat urgen). Dan ini merupakan tingkat yang tertinggi dari al-mashlahah yang perlu dijaga. Sebagai contoh, syari'at menetapkan hukuman nunuh bagi orang kafir yang menyesatkan orang banyak, begitu juga pembuat bid'ah yang menyuru orang lain mengikuti bid'ahnya; sebab perbuatan-perbuatan tersebut merusak agama. Begitu pula, syariat mewajibkan hukum qishash, karena dengan terpeliharanya diri (jiwa) manusia. Diwajibkannya had (hukuman cambuk) minuman khamar, karena dengannya akan terpelihara akal pikiran. Diwajibkannya had zina, karena dengannya terpelihara garis keturunan. Dan diwajibkannya menghukum perampok dan pencuru, karena dengannya akan terpelihara harta benda yang merupakan sumber penghidupan manusia dan memenuhi keperluan hidup mereka. ${ }^{24}$

Kemudian Imam al-Ghazali menerangkan peringkat yang ketiga dari maslaha, yaitu perkara yang tidak termasuk ke dalam al-Dharurat dan tidak pula termasuk ke dalam katagori al-hajat, tetapi digolongan ke dalam kelompok al-Tahsin (menambah baik) dan al-Tazyin (memerindah), gunanya adalah untuk menjaga dan memelihara cara-cara yang terbaik dalam adat (tradisi) dan Mu'amalat (interaksi) yang berlaaku dalam masyarakat. Contoh yang beliau kemukakan adalah tidak dibenarkan hamba sahaya menjadi saksi, walaupun fatwa dan riwayatnya diterima, karena level atau posisi hamba sahaya lebih rendah dibandingkan orang yang merdeka. Hal ini disebabkan kedudukan mereka lemah dan di bawah kuasa pemiliknya, sehingga tidak bisa dijadikan saksi dengan asumsi adanya tekanan-

${ }^{24}$ Abu Ishaq al-Syathibi, al-I'tisham, h.. 287-288 tekanan dan pihak majikan. ${ }^{25}$

Selanjutnya al-Ghazali memandang bahwa maslahat hijayat dan tahsiniyat tidak dapat dijadikan hijjah (dalil) dalam menetapkan hukum Islam, kecuali hajiyat yang menempati level daruriat. ${ }^{26}$ Pernyataan al-ghazali tentang hal ini tidak berada jauh dengan al-Syatibi.

Menurut al-Thufi, dalam muamalah dalil yang terkuat adalah maslahat, sedang dalam bidang ibadah dan hal yang disamakan dalam ibadah, dalil yang dipedomani adalah nash dan ijma'. Yang termasuk dalam hal yang disamakan dalam ibadah ialah ketentuan-ktentuan yang berbicara tentang hudud dan uqubat (ancamanancaman hukum atas pelaku tindak pidana), muqaddarat (ketentuan-ketentuan hukum yang memiliki ukuran dan batasan tertentu), yang semuanya didasarkan atas nash.

Pendapat at-Thufi yang menyatakan bahwa maslahat yang merupakan dalil terkuat dalam bidang muamalah mengandung arti bahwa jika terjadi pertentangan diantara maslahat dan dalildalil lainnya karena dalil lainnya mengandung kemudharatan, maka kecuali terhadap kemudharatan yang didaarkan atats dalil yang bersifat khas, maslahat wajib didahulukan atas dalil lain tersebut, melalui takhsis dan bayan.

Menurut at-Thufi, hadits nabi yang berbunyi la Dharar wa la Dhirara, adalah dalil yang bersifat khusus yang menjadi mukhashish terhadap semua ketentuan syara' yang mengandung kemudharatan, kecuali kemudharatan yang didasarkan atas nas yang bersifat khusus. Makna hadits ini bersifat qath'I sebab dilihat dari segi sanad, dukung oleh adanya sejumlah dalil baik yang berasalsejumlah dalil baik yang berasal dari ayat-ayat Alquran, hads, ijma, maupun logika, yang semuanya menunjukan bahwa allah memelihara kemaslahatan manusia.

Di samping itu menurutnya tak dapat disangkal fakta menunjukan bahwa Allah memelihara kemaslahatan manusia baik secara

\footnotetext{
${ }^{25}$ Abu Ishaq al-Syathibi, al-I'tisham, h.. 289

${ }^{26}$ Abu Ishaq al-Syathibi, al-I'tisham, h. 293-294
} 
umum maupun khusus, dalam bentuk umum Allah memelihara kemaslahatan manusia sejak penciptaannya sampai dengan meyediakan hal-hal yang mendukung kehidupan mereka. Sedangkan dalam bentuk khusus, Allah memberikan petunjuk agar manusia selamat diakhirat. Menurutnya, jika Allah memelihara kemaslahatan manusia baik secara umum maupun khusus, maka pemeliharaan kemaslahatan di bidang hukum merupakan suatu keniscayan dan lebih perlu, sebab itu bersifat umum. Dengan adanya pemeliharaan tersebut dibidang hukum, harta, darah dan kehormatan mereka menjadi terjamin. Karena alSyari' mengutamakan pemeliharaan kemaslahatan manusia di bidang hukum, maka kata at-Thufi dalam keadaan bagaimanapun keberadaan pemeliharaan kemaslahatan manusia tidak boleh diabaikan. Atas dasar itu, maslahat sebagai suatu dalil wajib didahulukan atas dalil syara' lainnya.

Selanjutnya at-Thufi mengemukakan alasan lain dengan menunjukan pembagian kemaslahatan ditinjau dari tujuan syara' kepada bidang ibadah dan yang disamakan dengannya, serta bidang muamalah dan yang disamakan denganlainnya. Ibdah dan yang disamakan dengannya dimaksudkan Allah menjadi haknya. Menurutnya, maka manusia tidak dapat mengetahui cara, ukuran, waktu dan tempat ibadah kecuali berdasarkan ketentuan yang ditetapkan Allah dalam bentuk nas dan ijma'. Oleh karena itu nas dan ijma' merupakan pedoman utama dalam menentukan hukum di bidang ibadah. Adapun muamalah dan yang disamakan dengannya, dimaksudkan untuk kepentingan manusia. Dalam bidang ini kemaslahatan manusia merupakan tujuan utama syara'. Oleh karena itu yang menjadi pedoman utma dalam penetapan hukum di bidang muamalah adlah kemaslahatan manusia. Tegasnya, dalil yang terkuat dalam bidang ibadah adalah nas dan ijma' sedangkan dalil yang terkuat dalam bidang muamalah adalah Riayah Al-Maslaha (prinsip memelihara kemaslahatan).

Alasan at-Thufi lainnya bahwa maslahat merupakan dalil terkuat di bidang muamalah ialah, dengan menyatakan bahwa pada dasarnya diantara semua dalil ada tiga dalil yang memiliki kemungkunan untuk dinilai sebagai dalil yang qath'I, yaitu ijma', nas, dan maslahat. Kemudian ia membuktikan bahwa diantara ketiganya hanya maslahat yang terkuat. Langkah pembuktiannya ialah,al-Thufi lebih dahulu mengajukan sebagai dalil yang menunjukan bahwa maslahat bersifat qath'i. selanjutnya ia membuktikan bahwa sebenarnya ijma' bersifat zhanni bukan qath'I, sedang yang lainnya adalah bersifat zhanni. Akan tetapi disamping nash yang qhat'I tersebut hanya sedikit jumlahnya, nash yang qath'I itu sendiri tidak mungkin bertentangan dengan maslahat. Berdasarkan alasan-alasan tersebut lalu ia menyimpulkan, jika dibidang muamalah terjadi pertentangan antara maslahat dan nash zhanni, maka maslahat yang bersifat qath'I yang wajib didahulukan antara keduannya, sebab yang qath'I wajib didahulukan atas yang zhanni.

Lain dengan at-Thuf, hujattul islam alGhazali mengtakan bahwa setiap maslaha yang bertentangan dengan Alquran, sunnah, atau ijma' adalah batal dan harus dibuang jauhjauh. Setiap kemaslahatan yang sejalan dengan tindakan syara' harus diterima untuk dijadikan pertimbangan dalam penetapan hukum Islam. ${ }^{27}$

Al-Ghazali menegaskan bahwa tujuan utama penetapan hukum islam untuk mewujudkan kemaslahatan umat manusia pada dua dimensi, yaitu duniawi dan ukhrawi, maka peranan maslahat dalam hukum Islam adalah sangat dominan dan menentukan dalam meng-istinbath hukum. Oleh sebab itu, Al-Ghazali membagi maslahat menjadi tiga ${ }^{28}$, yaitu:

1. Maslahat yang dibenarkan/ditentukan oleh nas/dalil tertentu. Inilah yang dikenal dengan maslahat mu'tabarah. Maslahat semacam ini dapat dibenarkan untuk menjadi pertimbnagan penerapan huku Islam dan termasuk ke dalam qiyas. Dalam hal ini, para pakar hukum Islam telah konsesius.

\footnotetext{
${ }^{27}$ Abu Ishaq al-Syathibi, al-I'tisham, h. 294

${ }^{28} \mathrm{Abu}$ Ishaq al-Syathibi, al-I'tisham, h. 284-286
} 
2. Maslahat yang dibatalkan/digugurkan oleh nas/dalil tertentu. Inilah yang dikenal dengan maslahat mulgah. Maslahat semacam ini tidak dapat dijadikan pertimbangan dalam menetapkan hukum Islam. Dalam hal ini, para pakar hukum Islam juga telah konsensus.

3. Pendapat apakah maslahah mursalah itu dapat dijadikan pertimbangan dalam penetapan hukum Islam ataukah tidak.

Dengan pertimbangan semacam itu, akan diketahui tentang persyaratan maslaha yang dapat dijadikan hujjah dan yang tidak dapat dijadikan hujjah. Dalam hal ini, al-Ghazali menyebutkan secara gamblang syarat-syarat muslaha mursalah yang dijadikan hujjah (dalil) dalam penetapan hukum, yaitu;

1. Maslahat itu sejalan dengan jenis tindakantindakan syar'/ penetapan hukum Islam (yang dimaksudkan untuk memelihara agama, akal, jiwa, harta, dan keturunan/ kehormatan). Inilah persyaratan ini bagi diterimannya maslaha mursalah. Maslahah mulgah (yang bertentangan dengan nas dan ijma') harus di tolak. Demikian pula maslaha gharibah (yang sama sekali tidak ada dalilnya, baik yang membenarkan maupun yang membatalkan). Bahkan al-Ghazali yang menyatakan maslahat semacam itu hakikatnya tidak ada. ${ }^{29}$

2. Maslahat itu harus berupa maslahat daruriat atau hajiah yang menempati kedudukan daruriah. Maslahat tahsiniat tidak dapat dijadikan hujjah/pertimbangan penetapan hukum Islam, kecuali ada dalil khusus yang menunjukkannya, yang berarti penetapan hukumnya itu lewat qiyas, bukan atas nama maslahah mursalah. ${ }^{30}$

Lebih tegas lagi, al-Ghazali menyatakan bahwa setiap maslahah yang bertentangan dengan Alquran, sunnah, atau ijma' adalah batal dan harus ditolak. Adapun kemaslahatan yang sejalan dengan syara' maka ia diterima untuk di-

\footnotetext{
${ }^{29}$ Abu Ishaq al-Syathibi, al-I'tisham, h. 294-296

${ }^{30}$ Abu Ishaq al-Syathibi, al-I'tisham, h. 310-311
}

jadikan pertimbangan dalam penetapan hukum Islam. ${ }^{31}$ Dengan pernyataan ini, al-Ghazali ingin menegaskan bahwa tak satupun hukum Islam yang kontra dengan kemaslahatan, atau dengan kata lain tak akan ditemukan hukum Islam yang menegaskan dan membuat mudharat umat Islam.

At-Thufi menganggap bahwa muslahat hanya ada pada masalah-masalah yang berkaitan dengan muamalat dan yang sejenis bukan pada masalah-masalah yang berhubungan dengan ibadat atau yang serupa. Sebab, masalah ibadat hanya hak syar'i. tidak mungkin seorang mengetahi hakikat yang terkandung di dalam ibadat, baik kualitas maupun kuantitas, waktu atau tempat, kecuali hanya menjalankan apa saja yang telah diperintahkan oleh tuhannya. Sebab, seorang pembantu tidak akan dikatakan sebagai seorang yang taat jika tidak menjalankan printah yang telah diucapkan oleh tuannya, atau mengerjakan apa saja yang sudah menjadi tugasnya. Demikian halnya dalam masalah ibadat, menurut at-thufi maslahat-maslahat yang tidak dapat diketahui adalah maslahat yang terkandung di dalam maslahat ibadat. Namun, mengenai maslahat yang bertalian dengan kehidupan sosial kaum mukllaf dan hak-hak mereka, hal ini dapat diketahui oleh mereka melalui akal pikiran mereka. Dengan kata lain, jika kami tidak melihat dalil syariat yang tidak menyebutkan maslahatnya, kami berpegang bahwa syariat telah membolehkan kami untuk mencari maslahat sendiri.

Pandangan at-Thufi tentang maslahat nampaknya bertitik tolak dari konsep maqasid at-tasri yang menegaskan bahwa hukum Islam disyaratkan untuk mewujudkan dan memelihara maslahat umat manusia. Konsep ini telah diakui oleh para ulama dan oleh karena itu mereka mempormulasasikan suatu kaidah yang cukup populer, "dimana ada maslahat" di sana ada hukum Allah.

Selanjutnya, al-Thufi menggunakan metode takhsis dan bayan dalam mendahulukan maslahat

\footnotetext{
${ }^{31}$ Abu Ishaq al-Syathibi, al-I'tisham, h. 311
} 
atas nas dan ijma', terdiri dari dua langkah secara bertahap, dalam arti, langkah kedua hanya dapat ditempuh jika langkah pertama tidak dapat diterapkan. Langkah yang pertama ialah dengan metode penggabungan dalil, sedangkan langkah yang kedua ialah dengan cara benar-benar mendahulukan maslahat atas nash dan ijma'. Akan tetapi langah kedua itu hanya mengandung arti tabdil (penggantian hukum), bukan naskh (pembatalan kandungan dalil).

Mendahulukan maslahat dalam bentuk tabdil mengandung arti bahwa suatu ketentuan hukum yang semula berlaku dapat diganti dengan ketentuan hukum lain, karena alasan kemaslahatan. Namun, dengan alasan kemaslahatan juga ketentuan hukum yang pertama dapat kembali diberlakukan menggantikan ketentuan hukum yang kedua, karena kemaslahatan menghendaki agar ketentuan yang pertama tersebut diperlakukan kembali.

Dalam buku Syafa' al-Ghalil, al-Ghazali menyinggung maqashid al-syari'ah ketka membahas "qiyas". Beliau menerangkan bahwa salah satu cara menetapkan 'illat hukum adalah adanya al-munasabah. Yang beliau maksud dengan al-munasabah dalam maslah ini adalah "adanya keserasian atau kelayakan antara makna yang terkandung dalam teks dengan al-maslahah. Sedangkan al-maslahah yang dimaksud adalah "mendatangkan manfaat dan menolak kemudaratan. "Dengan kata lain, munasabah dalam hukum Islam itu adalah untuk memelihara maksud (tujuan) syara' mewujudkan kemaslahatan dan menjauhkan kemudharatan. ${ }^{32}$

Kemudian beliau membagi maksud atau tujuan syara' itu kepada kedua macam, yaitu daniy (agama) dan dunyawi (keduniaan). Masing-masing dari padanya terbagi pula kepada dua jenis, yakni tahshil (menghasilkan) dan ibqa' (mengekalkan). Yang dimaksud dengan tahshil (menghasilkan) adalah menghasilkan atau mendatangkan manfaat, sedangkan ibqa' (mengekalkan) adalah

${ }^{32}$ Abu Hamid al-Ghazali, Syifa' al-Ghalil fi Bayan al-Syibh wa Mukhil wa Masalik al-Talil, Hamad al-Kubaisiy (ed), (Baghdad: al-Irsyad, t.th.), h.159 mempertahankan eksistensi suatu dan menolak kemudaratan dari padanya. Maksudnya apa yang sudah ada itu harus dipertahankan, dijaga dan dipelihara supaya tetap eksis dan jangan terjadi padanya kemusharatan. Dengan demikian, memelihara tujuan-tujuan syari'ah (maqashid alSyari'ah) adalah menjaga supaya yang ada itu tetap eksis (jangan sampai tiada) dan menolak kemudharatan dari padanya (jangan sampai rusak) serta mewujudkan kemaslahatan (manfaat) baik dalam bidang agama maupun kehidupan duniawi. ${ }^{33}$ Imam al-Ghazali menjelaskan bahwa semua jenis munasabah bertujuan menjaga maqashid syariah, apa saja yang tidak sesuai dengan maqashid syariah maka itu bukanlah munasabah, dan apa saja yang membawa kepada maqashid syari'ah maka itu adalah munasabah. ${ }^{34}$

Selanjutnya Imam al-Ghazali menerangkan maksud atau tujuan-tujuan syari'at itu adalah untuk memelihara jiwa, akal, keturunan manusia, dan harta. Karena itu, bagi yang membunuh ditetapkannya hukuman qishashh, tujuannya adalah untuk memelihara diri dan jiwa manusia supaya tetap eksis. Ketetapan ini adalah sangat rasional (mq'qul) dan cocok (munasib) dengan tujuan ditetapkannya huku (maqashid al-Syari ah), yakni mendatangkan kemaslahatan. Begitupun diharamkan meminum khamar, karena ia bisa merusak akal. Sedangkan menjaga akal merupakan tujuan syari'ah karena dengan akal manusia dapat memahami sesuatu. Demikian pula menjaga alat kelamin manusia, agar tidak terjadi keracunan keturunan. Begitu pula terhadap harta benda, menjaganya merupakan tujuan syari'ah. Hal ini dilihat pada larangannya mengambil hak orang lain, karena itu diwajibkan mengganti barang orang lain tersebut, dan diperintahkannya memotong tangan orang yang mencuri.

Di dalam Alquran, Allah Swt. Telah mengingatkan tujuan diisyaratkannya qishash, sebagaimana terdapat dalam surat Al-Baqarah ayat 179 :

\footnotetext{
${ }^{33}$ Abu Hamid al-Ghazali, Syifá al-Ghalil..., h. 159.

${ }^{34}$ Abu Hamid al-Ghazali, Syifa' al-Ghalil..., h. 159.
} 


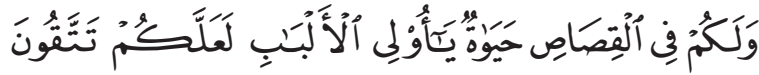
"Dan dalam qishaash itu ada (jaminan kelangsungan) hidup bagimu, Hai orang-orang yang berakal, supaya kamu bertakwa"

Begitu pula mengenai kerusakan yang timbul akibat minum Khamar, sebagaimana terdapat dalam firmannya pada Al-Maidah ayat 91:

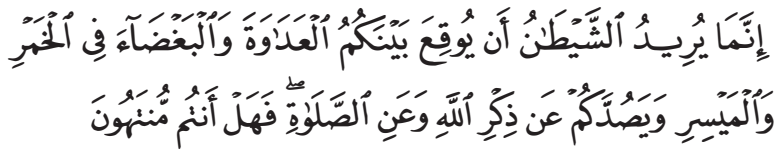

"Sesungguhnya syaitan itu bermaksud hendak menimbulkan permusuhan dan kebencian di antara kamu lantaran (meminum) khamar dan berjudi itu, dan menghalangi kamu dari mengingat Allah dan salat; maka berhentilah kamu (dari mengerjakan pekerjaan itu)"

Penggalan kata "permusuhan dan kebencian diantara kamu" merupakan persoalan yang dapat mendatangkan bahaya (mudharat), karena termasuk pada perbuatan yang dilarang, sedangkan kata "menghalangi kamu dari mengingat Allah dan shalat" merupakan persoalan yang dapat merusak agama.

Sedangkan kemaslahatan (maslahah) yang dibawa oleh agama, dapat dilihat dari kewajiban sholat misalnya. Sepertimana diterangkan dalam firmannya surat al-Ankabut ayat 45:

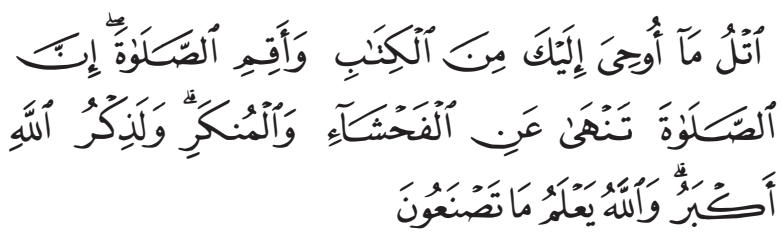

"Bacalah apa yang telah diwahyukan kepadamu, Yaitu Al kitab (Al Quran) dan dirikanlah shalat. Sesungguhnyn shalat itu mencegah dari (perbuatan- perbuatan) keji dan mungkar. dan Sesungguhnya mengingat Allah (shalat) adalah lebih besar (keutamaannya dari ibadat-ibadat yang lain). dan Allah mengetahui apa yang kamu kerjakan"

Pencegahan dari perbuatan keji tersebut merupakan inti maslahah yang dibawa agama, yang dengannya juga tercipta kemaslahatan dunia. Seterusnya, imam al-Ghazali menegaskan bahwa semua munasabah hukum Islam tersebut rujukannya, adalah memelihara tujuan-tujuan syara, namun tujuan-tujuan syara' itu berbagi pula kepada beberapa tingkatan di antaranya:

1. Al-Dharurat (kepentingan yang paling urgen atau kebutuhan primer), merupakan tingkatan yang paling tinggi. Misalnya memelihara atau menjaga nyawa. Contoh yang paling sesuai dengan masalah ini adalah pelaksanaan hukum qishas. Begitu juga juga dengan urgenya menjaga akal dengan diharamkannya minuman khamar, dan sebagainya. Belakangan konsep ini disebut dengan "al-Dharurat al-Khamsah".

2. Al-hajat (hajat atau kepentingan yang diperlakukan atau kebetulan sekunder), misalnya diberikan hak kuasa kepada wali untuk memelihara anak gadisnya yang masih belia untuk menjaga dan memelihara adanya kafa'ah (keserasian/kecocokan) di antara suami istri dan terjaganya mahar misil (mahar standar dalam keluarga).

3. Al-Tahsinan dan al-Tazyinat (kepentingan yang memperindah dan memperbagus atau kebutuhan tersier). Kepentingan ini tidak termasuk ke dalam al-dharurat dan tidak pula al-hajat, tetapi hanya berfungsi sebagai hiasan yang memperindah saja. Contohnya, saksi hamba sahaya tidak diterima oleh kasuskasus yang melibatkan orang mereka, karena perbedaan status keduanya. ${ }^{35}$

Dari pembahasan di atas, dapat ditarik kesimpulan bahwa antara al-Thufi, al-Ghazali dan al-Syatibi terdapat benang merah yang kuat dalam rancang bangun maqashid al-syari ah, hanya dalam beberapa hal terdapat perbedaan sudut pandang.

Al-Syathibi yang hidup terakhir dan dianggap sebagai 'bapak' maqashid al-Syari'ah, banyak terpengaruh dari pemikiran para ulama sebelumnya, khususnya para ushuliyyun dan pengikut mazhab Malikiah. Contoh nyata istifadah al-Syathibi pada ushuliyun dapat dilacak pada

\footnotetext{
${ }^{35}$ Abu Hamid al-Ghazali, Syifa' al-Ghalil..., h. 160
} 
pembagian konsep masalih menjadi 3; dharuriyat, hajiyat dan tahsiniyat, dan pembagian dharuriat menjadi 5; hifz al-din, hifz al-nafs, al-aql, al-nasl, al-mal. Perlu dicatat bahwa al-Juwaini lah yang pertama kali memperkenalkan konsep ini dalam kitabnya al-Burhan. Sedangkan pengaruh dari al-Ghazali, dapat kita temukan pada puluhan kali penyebutan nama al-Ghazali, baik di alMuwafaqat ataupun di al-I'tisham. Sebagagai mengenal pembahasan makna sah dan batalnya suatu amal, ia mengemukakannya sebagai berikut "bahwa suatu amalan yang yang sah adalah amal yang baik dimata Allah dan mendapatkan pahala atas perbuatannya tersebut, dan bukan semata amal yang batal yang terpenuhi syarat dan rukunnya saja, sementara amal yang batal sebaliknya. Hal ini telah disinggung oleh para ulama akhlak semisal al-Ghazali dalam bab niat dan iklasnya”. Sedangkan pengaruh dari Izzudin "Abd al-Salam dan muridnya, al-Qarafy terlihat pada pasal musyaqqah dan pembagiannya, masyaqqah mulazamah li al-taklifyang kemudian dikembangkan lebih dalam oleh al-Syathibi. Sementara bagi seorang penganut Malikiah taat, yang mempunyai karakter khas sebagai madzhab maslahah, istislah, ihtihsan dan tafsir maslahah terhadap teks, dan jalb al-manafi wa dar' almafasid terhadap konteks turut memberikan sumbangsih cukup besar pada cara pandang alSyathibi. ${ }^{36}$

Adapun Najmuddin al-Thufi terksesan menggunakan metodologi liberalistik, yakni usul fikih yang menonjolkan karakter pemikiran liberal dan radikal. Kaitannya dengan membahas ini, al-Thufi dalam salah satu teorinya mengatakan bahwa apabila terjadi ta'arud antara nash, ijma' dengan maslahah, maka maslahah harus didahulukan. Karena bagi at-Thufi maslahah merupakan tujuan atau esensi pokok, sementara nash dan ijma' hanyalah sarana. Artinya, ketika esensi bertentangan dengan sarana, esensilah yang harus didahulukan.

Sementara al-Syatibi terkesan menggunakan metedologi utilitarianistik yakni usul fikih

\footnotetext{
${ }^{36}$ Abu Hamid al-Ghazali, Syifa' al-Ghalil..., h. 318
}

yang secara luas menjelaskan relung-relung maqashid al-syari'ah dengan didukung oleh teks atau nas. Jadi menurut al-Syathbi, semua hukum syara yang didukung oleh nas pasti mendukung kemaslahatan manusia. Namun, ternyata ada bagian hukum yang tidak mengandung kemaslahatan atau kemaslahatan itu berseberangan dengan nas. Konsekuensinya, maka bagi al-Syatibi hukum itu harus ditolak atau keberadaan hukum itu adalah batil. Namun, kenyataannya bagi al-Syatibi bukan berarti hukum itu harus ditolak, akan tetapi hukum itu di mauqufkan dengan mengembalikan bahwa semua hukum yang diturunkan tetap mengandung kemaslahatan, baik itu bisa diketahui secara langsung bahkan sama sekali tidak diketahui oleh akal manusia dengan keterbatasannya.

\section{Penutup}

Mengakhiri tulisan ini, ada bebera hal yang dapat disimpulkan bahwa maksud segala bentuk hukum syariah yang disyariatkan Allah bertujuan untuk mendatangkan kemaslahatan dan menghindarkan kemudharatan, baik di dunia maupun akhirat. Kemaslahatan itu, ada yang dalam bentuk al-dharuriyyat (primer), al-hajiyat (sekunder), dan al-tahsiniyyat (tersier), dan terakomodir dalam lima prinsip pokok yaitu melihara agama, jiwa,akal, keturunan dan harta benda. Segala sesuatu yang mengandung makna pemeliharaan/penjagaan terhadap kelima maqashid al-syari'ah, dinamakan mafsadah, menolak/menghilangkan mafsadah berarti maslahah. Tujuan dan inti seluruh ajaran Islam (Alquran dan hadis) adalah kemaslahatan. Maka harus mengedepankan kemaslahatan atas teksteks agama dan ijma' dalam wilayah muamalah dan adat bila terjadi kontradiksi antara keduanya. Kemaslahatan yang disiapkan manusia harus diikutkan pada kemaslahatan yang dicanangkan teks bila terjadi kontradiksi antara keduannya.

Kemaslahatan yang dalam istilah al-Ghazali dan al-Syathibi disebut kullinya al-Syari'ah adalah bersifat qath'iy. Al-Thufi tidak membagi 
maslahah ke dalam dharuriah, hajiyah, dan tahsiniyah. Bagi al-Thufi, maslahah adalah maslahah, tidak perlu di bagi-bagi. Al-Syathibi membaginya menjadi tiga macam, yaitu: maslahah dharuriah, hajiyah dan tahsiniyah. Ketiga bagian ini bersifat hierarkis. Antara at-Thufi, al-Ghazali dan al-Syathibi sepakat bahwa kemaslahatan dimaksud, hakikatnya kembali pada perlindungan terhadap manusia itu sendiri, namun menurut al-Thufi mashlahah adalah dalil mandiri yang paling otoritatif untuk menentukan kebijakan hukum. Padahal, kemaslahatan bukan dalil otoritatif untuk menentukan kebijakan hukum. Kemaslahatan bukan dalil hukum, melainkan sebagai inti dan tujuan sebuah hukum. Menurutnya, seluruh ajaran-ajaran syariah Islam memiliki hubungan kausalitas (muamalah) dengan kemaslahatan dalam wilayah adat dan muamalah. Akal (intelektualitas) manusia normal maupu mengetahui dan menemukan kemaslahatan dalam wilayah muamalah dan adat (tradisi), tapi tidak dalam wilayah ibadah. Pemikiran atThufi tentang mashlahat merupakan dalil terkuat dalam bidang muamalah, hal ini dapat menjadikan hukum Islam mampu menjawab tantangan kemajuan dewasa ini. Sebab konsep tersebut dapat melahirkan hukum Islam yang lebih substantif dibanding dengan konsep dalil lainnya.

\section{Pustaka Acuan}

Ahwani, Ahmad Fuad al-, Sirah al-Ghazali wa al-Aqwal al-Mutaqaddimin Fih. Damaskus: Dar al-Fikr. t.th.

Bukhari, Muhammad bin Ismail bin Ibrahim bin al-Mughirah al-, Shahih al-Bukhari. Juz I. t.th.

Buthi, Muhammad Said Ramadhan al-, AlDhawabit al-Mashlahat $f i$ al-Syariah alIslamiyah, Beirut: Muasasah al-Risalah, 1977.

Dimasqy, Ibn Syuhbah Taqiqyuddin Abi Bakr bin Ahmad bin Qadhi Syuhbah al-Asady al-, Tabaqat al-Fuqaha al-Syafi'iyyah. Cairo: Maktabah al-Tsaqofah al-Diniyah. t.th.
Dunya, Sulaiman, Al-Haqiqah Fi Nazhr alGhazali, Kairo: Dar al-Ma'arif. 1971.

Fasi, 'Alal al-, Maqashid al-Syari'ah wa Makanatuha, Mesir: Dar Al-Ma'arif, 1971.

Ghazali, Abu Hamid, Al-Mustashfa Min 'Ilmi al-Ushul. Juz II. Beirut: Dar Ihya al-Turats al-Arabiy. t.th.

Ghazali, Abu Hamid, Syifa' al-Ghalil fi Bayan al-Syabah wa al Mukhil wa Masalik al-Talil. Beirut: Dar al-Kutub al-'Ilmiyah, 1420 H/1999 M. Cet ke-1.

Jauziyyah, Ibn Qayyim al-, I'lam al Muwaqiin 'an Rab al-Alamin, Beirut: Dar al-Fikr, t.th., Juz III

Juwaini, Al-Imam al-Haramain Abi al-Ma'ali Abd al-Malik Ibn Abdulullah ibn Yusuf al-, Al-Burhani fi Ushul al-Fiqh, Kairo: Dar alAnshar, 1400 H. Juz I.

Khalaf, Abdul Wahab, Ilmu Ushul Figh. Kairo: Matba'ah al-Da'wah al-Islamiyah, 1990, Cet. VIII.

Khalikan, Abu 'Abbas Syamsuddin Ahmad bin Muhammad bin Abi Bakr ibn, Wafayat alA'yan wa Anba' Anba' al-Zaman, Beirut: Dar al-Shadir, 1971, Juz IV. Cet. I.

Manzur, Ibn, Lisanu al-Arabi.Mesir: Muassasah al-Misriyah al-'Ammah li al-Ta'lif wa al-Anba wa al-Da'wah. t.th.

Raisuni, Ahmad, Nadhariyyat al-Maqashid Inda al-Imam al-Syatibi. Beirut: al-Muassasah al-Jamiiyyah Liddirasat wa al-Nasyr wa alTauzi.1992.

Subuki, Ibn al-, Tabaqat al-Syafi'iyyah al-Kubra, Cairo: Matba'ah 'Isa al-Babi al-Halabi, t.th., Jilid VI

Syamy, Sholeh Ahmad, Al-Imam al-Ghazali Hujjatu al-Islam wa Mujaddid al-Miat al-Khamisah, (A'lam al-Muslimin Seri 43). Damsyiq: Dar alQalam, 1993/1413, Cet. ke-1.

Syatibi, Abu Ishaq al-, Al-Muwafaqat Fi Ushul al-Syariah. Jilid II. Mesir: Dar al-Fikr alArabi. t.th.

Syaukani, Muhammad bin Ali bin Muhammad al-, Irsyad al-Fuhul.Dar al-Fikr. t.th. 
Zahrah, Muhammad Abu, Ushulal-Fiqh, Mesir: Dar al-Fikr al-Araby, 1958.
Zaidan, Abdul Karim, Al-Wajiz Fi Ushul alFiqh, Baghdad: Dar al-Arabiyah Lit Tiba'ah, 1977, Cet. VI. 